\title{
Anemia and red blood cell transfusion in critically ill cardiac patients
}

\author{
Geneviève Du Pont-Thibodeau, Karen Harrington and Jacques Lacroix*
}

\begin{abstract}
Anemia and red blood cell (RBC) transfusion occur frequently in hospitalized patients with cardiac disease. In this narrative review, we report the epidemiology of anemia and RBC transfusion in hospitalized adults and children (excluding premature neonates) with cardiac disease, and on the outcome of anemic and transfused cardiac patients. Both anemia and RBC transfusion are common in cardiac patients, and both are associated with mortality. RBC transfusion is the only way to rapidly treat severe anemia, but is not completely safe. In addition to hemoglobin $(\mathrm{Hb})$ concentration, the determinant(s) that should drive a practitioner to prescribe a RBC transfusion to cardiac patients are currently unclear. In stable acyanotic cardiac patients, $\mathrm{Hb}$ level above $70 \mathrm{~g} / \mathrm{L}$ in children and above 70 to $80 \mathrm{~g} / \mathrm{L}$ in adults appears safe. In cyanotic children, Hb level above $90 \mathrm{~g} / \mathrm{L}$ appears safe. The appropriate threshold $\mathrm{Hb}$ level for unstable cardiac patients and for children younger than 28 days is unknown. The optimal transfusion strategy in cardiac patients is not well characterized. The threshold at which the risk of anemia outweighs the risk of transfusion is not known. More studies are needed to determine when RBC transfusion is indicated in hospitalized patients with cardiac disease.
\end{abstract}

Keywords: Blood; Cardiac; Critical care; Erythrocyte; Hemoglobin; Intensive care; Practice; Risk factors; Surgery; Transfusion

\section{Review} Introduction

Red blood cell (RBC) transfusion is common in critically ill adults and children [1-3]. Patients with cardiac disease are transfused at higher hemoglobin $(\mathrm{Hb})$ thresholds than those with non-cardiac illness [1-3]. Both anemia and RBC transfusion are associated with increased mortality in cardiac patients. The risk/benefit balance of $\mathrm{RBC}$ transfusion in critically ill cardiac patients is currently a matter of debate.

This narrative review critically appraises the available data on the relationship between anemia, RBC transfusion and outcome of critically ill adults and children with cardiac disease. We discuss the prevalence and risks of anemia in the ICU, the rationale for RBC transfusion, the evidence supporting restrictive transfusion strategies, and the growing interest in goal-directed transfusion therapy. Premature infants and intraoperative transfusions will not be addressed in this paper, nor will a detailed

\footnotetext{
* Correspondence: j_lacroix@videotron.ca

Sainte-Justine Hospital, Room 3431, 3175 Côte Sainte-Catherine, Montreal, QC H3T 1C5, Canada
}

discussion of the relationship between length of storage of $\mathrm{RBC}$ units and outcomes, since the latter is discussed in other papers [4-7].

\section{Anemia}

The prevalence of anemia in adults with heart failure ranges from 18 to $38 \%$ [8]; it was $19.1 \%$ in 27 observational studies indexed before July 2011 that enrolled 233,144 patients with acute coronary syndrome [9]. Anemia may result in insufficient oxygen delivery $\left(\mathrm{DO}_{2}\right)$ to vital organs and tissues if $\mathrm{DO}_{2}$ drops below a critical $\mathrm{DO}_{2}$ (Figure 1). $\mathrm{DO}_{2}$ is determined by cardiac output (Q') and arterial content in:

$$
\begin{aligned}
& \mathrm{DO}_{2}=\mathrm{Q}^{\prime} \times \mathrm{CaO}_{2} \\
& \text { and } \mathrm{CaO}_{2}=\left\{\left(\mathrm{Hb} \times \mathrm{SaO}_{2} \times 1.39\right)+\left(\mathrm{PaO}_{2} \times 0.0031\right)\right\}[10]
\end{aligned}
$$

Any drop of the $\mathrm{Hb}$ level decreases $\mathrm{CaO}_{2}$ and $\mathrm{DO}_{2}$ if the compensatory increase of Q' is not high enough. Anemia may be poorly tolerated by patients with cardiac failure and/or coronary disease because their ability to increase cardiac output to compensate for anemia is limited $[11,12]$.

\section{实 Springer}




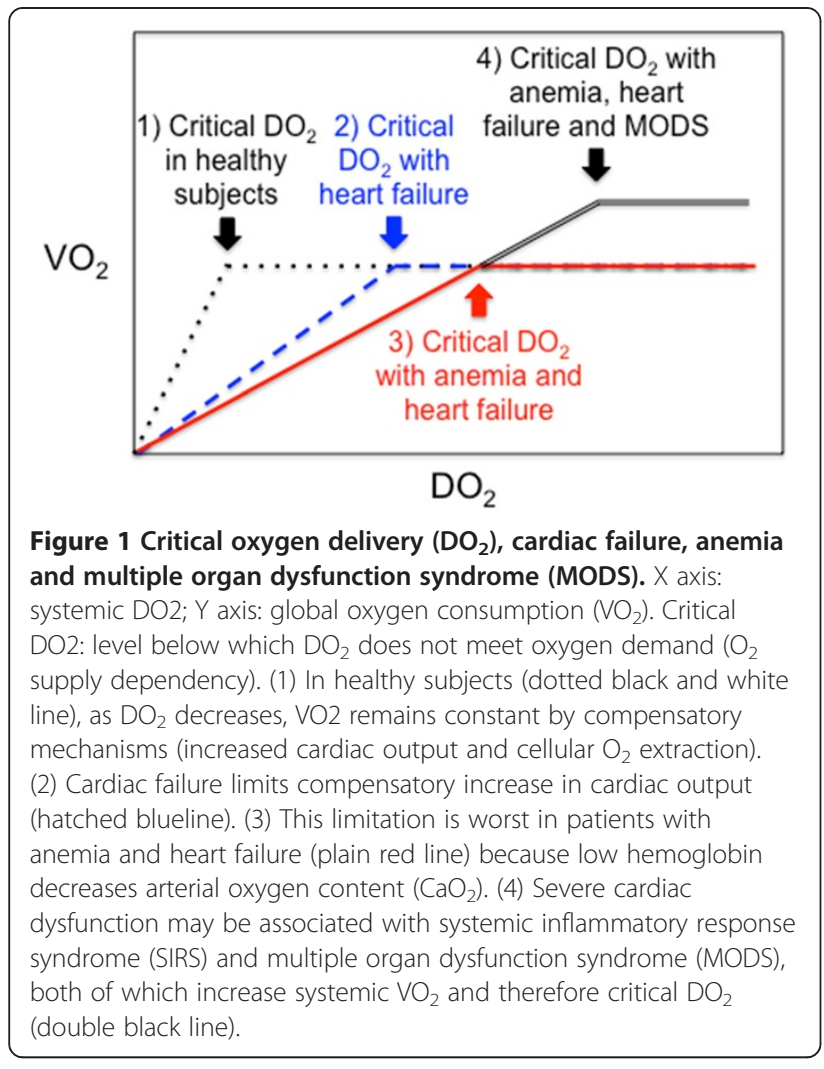

Carson et al. [13] studied the association between anemia and surgical mortality in 1,958 Jehovah's Witness patients with cardiovascular disease who refused transfusion; the risk of mortality was inversely related to $\mathrm{Hb}$ level (Figure 2). Table 1 summarizes the results of two meta-analyses $[9,14]$ and six observational studies [15-20] on the relationship in cardiac adults between anemia and adverse outcomes; a statistically significant association is reported in almost each instance. However, it must be underlined that the relationship between anemia and outcome is fundamentally confounded in all these studies by co-morbidities that might have caused the anemia (renal failure, gastro-intestinal bleeding, iron deficiency, and so on).

A number of host characteristics specific to children, like growth, fetal $\mathrm{Hb}$, different cardiac diseases and physiology, may impair their adaptive mechanisms to anemia. There are few data on the relationship between anemia and outcomes in cardiac children. Kammache et al. [21] reported some anemia $(\mathrm{Hb}<100 \mathrm{~g} / \mathrm{L})$ in $24 \%$ of 218 children with idiopathic dilated cardiomyopathy; mortality was more frequent in anemic children.

\section{Transfusion}

In the United States, $7.8 \%$ to $92.8 \%$ of adults undergoing cardiac surgery are transfused [22-24]. A transfusion is

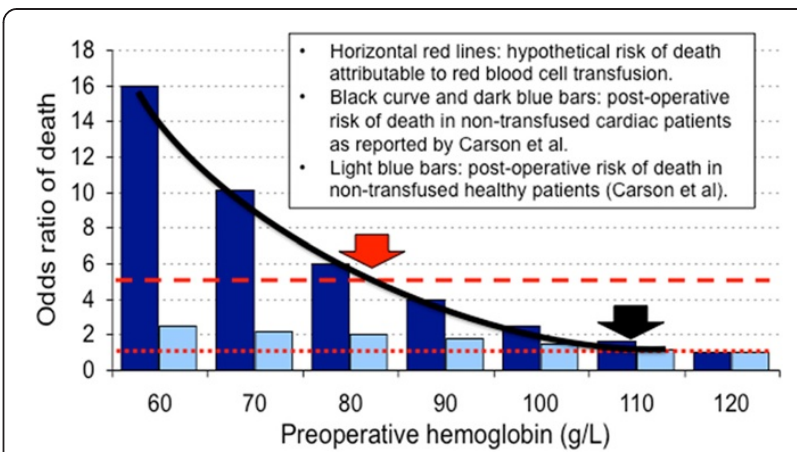

Figure 2 Cost-benefit analysis of red blood cell (RBC) transfusion. The background histogram is drawn from data published by Carson et al. [13] (with permission) illustrating the relationship between pre-operative anemia and surgical mortality in 1,958 Jehovah's Witness patients. Dark blue bars: preoperative hemoglobin $(\mathrm{Hb})$ versus odds ratio (OR) of death in cardiac patients (risk of death increases as $\mathrm{Hb}$ level falls). Light blue bars: pre- $\mathrm{Hb}$ versus $\mathrm{OR}$ of death in patients who were healthy before surgery. We draw on this histogram: (1) dotted horizontal red line: no risk of mortality attributable to $\mathrm{RBC}$ transfusion $(\mathrm{OR}=1)$; (2) hatched horizontal red line: hypothetical higher risk of mortality attributable to $\mathrm{RBC}$ transfusion $(\mathrm{OR}=5)$; (3) plain curved black line: pre-operative $\mathrm{Hb}$ versus odds ratio $(\mathrm{OR})$ of death in cardiac patients. A RBC transfusion is probably more useful than harmful when $\mathrm{Hb}$ level is below the intersection between the black curve describing the risk of mortality associated with anemia and the red line describing the risk of mortality attributable to RBC transfusion. If RBC transfusions are perfectly safe $(O R=1)$, the dotted horizontal red line and the black curve cross together at a $\mathrm{Hb}$ level of about $110 \mathrm{~g} / \mathrm{L}$ (black arrow). If the risk of mortality attributable to RBC transfusion is high (for example, $\mathrm{OR}=5$ ), the hatched horizontal red line and the black curve cross together at a $\mathrm{Hb}$ level of about $80 \mathrm{~g} / \mathrm{L}$ (red arrow). Where the true curve lies for cardiac patients is unknown. The curved line would probably move to the right in severely ill cardiac patients, and to the left if cardiac dysfunction is milder. The actual risk of death attributable to RBC transfusions in different cardiac populations remains to be determined.

given after cardiac surgery in $38 \%$ to $74 \%$ of children [3,25-28].

$\mathrm{RBC}$ transfusions are sometimes given to cardiac patients to rapidly replace blood volume in cases of postoperative blood losses [29]. In the absence of active bleeding, some practitioners declare that low $\mathrm{Hb}$ concentration and/or signs of inadequate $\mathrm{DO}_{2}$ (low central venous $\mathrm{O}_{2}$ saturation $\left(\mathrm{ScvO}_{2}\right)$, high lactate level, low $\mathrm{SaO}_{2} / \mathrm{FiO}_{2}$ ratio) would prompt them to prescribe RBC transfusions in this population [29]. There is no doubt that $\mathrm{Hb}$ level is a very important determinant of RBC transfusions in critically ill patients [30-32]. However, there are data suggesting that $\mathrm{Hb}$ level is not the only determinant of $\mathrm{RBC}$ transfusions in cardiac patients. In a retrospective study on transfusions in pediatric cardiac ICU [24], admission $\mathrm{Hb}$ ranged from 141 to $150 \mathrm{~g} / \mathrm{L}$, nadir $\mathrm{Hb}$ level was $121 \mathrm{~g} / \mathrm{L}$ in patients who were not 
Table 1 Anemia and outcomes in cardiac adults: observations studies

\begin{tabular}{|c|c|c|c|c|}
\hline & Health problem & Patients & Studies & Risk \\
\hline Outcome & & (n) & (n) & $(95 \% \mathrm{Cl})$ \\
\hline \multicolumn{5}{|l|}{ Meta-analyses } \\
\hline Mortality $^{\mathrm{a}}[14]$ & ACS & 51,449 & 10 & aOR: 1.49 (1.24 to 1.79$)$ \\
\hline Mortality ${ }^{\mathrm{b}}[9]$ & ACS & 171,915 & 27 & aHR: 1.49 (1.23 to 1.81$)$ \\
\hline \multicolumn{5}{|c|}{ Studies not included in the meta-analyses } \\
\hline Mortality [15] & New heart failure & 12,065 & 1 & aHR: 1.34 (1.24 to 1.46$)$ \\
\hline Mortality [16] & $\mathrm{PCl}$ & 6,116 & 1 & aHR: 1.8 (1.3 to 2.3$)$ \\
\hline Mortality [17] & $\mathrm{PCl}$ & 48,851 & 1 & aOR: 2.29 (1.79 to 2.92$)$ \\
\hline Mortality [18] & Cardiac surgery & 13,843 & 1 & $12.5 \%$ versus $7.5 \%, P=0.014$ \\
\hline Mortality [19] & CABG & 2,102 & 1 & aOR: 0.99 (0.98 to 1.0$)$ \\
\hline Mortality [20] & ACS & 7,922 & 1 & aOR: 1.71 (1.34 to 2.17$)$ \\
\hline \multicolumn{5}{|c|}{ Meta-analyses on other outcomes } \\
\hline Heart failure ${ }^{a}[14]$ & ACS & 152,849 & 5 & OR: 1.96 (1.47 to 2.62 ) \\
\hline Cardiogenic shock ${ }^{\mathrm{a}}$ [14] & ACS & 129,136 & 4 & OR: 1.95 (1.04 to 2.64$)$ \\
\hline Reinfarction ${ }^{\mathrm{b}}$ [9] & ACS & 22,115 & 6 & RR: 1.25 (1.02 to 1.53$)$ \\
\hline
\end{tabular}

ACS: acute coronary syndrome; aHR: adjusted HR; aOR: adjusted odds ratio; CABG: coronary artery bypass graft; Cl: confidence interval; HR: hazard ratio; OR: odds ratio; $\mathrm{PCl}$ : percutaneous coronary intervention; RR: relative risk.

This table reports data from two meta-analyses $[9,14]$ and six observational studies [15-20] that were not included in these meta-analyses.

${ }^{a}$ Overall, the meta analysis conducted by Liu et al. [14] included 241,293 patients enrolled in 19 studies; the analysis on mortality (10 studies) disclosed a very important heterogeneity $\left(I^{2}=84 \%\right)$.

${ }^{b}$ Overall, the meta analysis conducted by Lawler et al. [9] included 233,144 patients. The analyses on mortality and reinfarction included 27 and 10 studies respectively; an important heterogeneity was found in both instances $\left(I^{2}=98.2 \%\right.$ and $48.4 \%$ respectively).

transfused, $119 \mathrm{~g} / \mathrm{L}$ in a low transfusion group, and $115 \mathrm{~g} / \mathrm{L}$ in a high transfusion group, suggesting that transfusions may have been given for reasons other than anemia. Age below one year, low weight, high severity of illness as measured by the acute physiology and chronic health evaluation (APACHE) or pediatric risk of mortality (PRISM) score, cardiopulmonary bypass, cyanotic heart condition and lower admission $\mathrm{Hb}$ level are also reported to be independently associated with increased administration of RBC transfusions [24,33].

\section{Risks and benefits of RBC transfusions}

\section{Non-cardiac patients}

$\mathrm{RBC}$ transfusion should be given only when the risk/benefit ratio is favorable (ratio $<1$ ). The threshold at which the risks of anemia outweigh the risks of transfusion is currently unknown.

There are little available hard data on the clinical benefits of RBC transfusion. In a prospective study that enrolled 303 Kenyan children with $\mathrm{Hb}$ below $50 \mathrm{~g} / \mathrm{L}$ at hospitalization, 116 (38\%) did not receive a transfusion, mostly because of blood unavailability, while 187 did; the mortality was significantly higher in non-transfused children $(41.4 \%$ versus $21.4 \%, P<0.001)$ [34]. This study suggests that $\mathrm{RBC}$ transfusion may improve the survival of anemic hospitalized patients with $\mathrm{Hb}$ level below $50 \mathrm{~g} / \mathrm{L}$, but what threshold above $50 \mathrm{~g} / \mathrm{L}$ should be used to prescribe a RBC transfusion in cardiac patients remains a matter of debate.

\section{Adult cardiac patients}

The available evidence suggests that RBC transfusion in patients with cardiac disease is an independent risk factor of mortality (Table 2).

Three studies reported some transfusion benefits if the $\mathrm{Hb}$ level is low $(<80 \mathrm{~g} / \mathrm{L})$, but they also reported harm with high $\mathrm{Hb}$ level $[35,36,46]$. A retrospective descriptive epidemiological study of 78,974 patients older than 65 years with acute myocardial infarction showed that RBC transfusion was associated with a lower risk of 30-day mortality if hematocrit was below $24 \%$ (odds ratio (OR): 0.22; $95 \%$ CI: 0.11 to 0.45 ) or between $30 \%$ and $33 \%$ (OR: 0.69 ; 95\% CI: 0.53 to 0.89 ), but not in cardiac patients with hematocrit above 33\% [46]. Alexander et al. [35] reported that $\mathrm{RBC}$ transfusion tended to have a beneficial impact on mortality if the nadir hematocrit was $\leq 24 \%$ (adjusted odds ratio (aOR): 0.68; 95\% CI: 0.45 to 1.02), but the opposite was found if it was $>30 \%$ (aOR: 3.47; 95\% CI: 2.30 to 5.23). Aronson et al. [36] reported that RBC transfusion in patients with myocardial infarction decreased the risk of mortality if the pretransfusion $\mathrm{Hb}$ level was $\leq 80 \mathrm{~g} / \mathrm{L}$ (adjusted hazard ratio (aHR): 0.13: $95 \%$ CI: 0.03 to 0.65 ), but the risk was increased if the $\mathrm{Hb}$ level was $>80 \mathrm{~g} / \mathrm{L}$ (aHR: 2.2; 95\% CI: 1.5 to 3.3). Shehata et al. [19] reported a lower risk 
Table 2 Red blood cell (RBC) transfusions and outcomes in cardiac patients: observational studies ${ }^{\mathrm{a}}$

\begin{tabular}{|c|c|c|c|c|}
\hline Outcome, first author, year ${ }^{b}$ & Health problem & $\begin{array}{l}\text { Patients } \\
\text { (n) }\end{array}$ & $\begin{array}{l}\text { Risk }^{c} \\
(95 \% \text { Cl) }\end{array}$ & $P$-value \\
\hline \multicolumn{5}{|l|}{ Outcome: mortality in adults } \\
\hline \multirow[t]{5}{*}{ Mortality, Alexander, 2008 [35] } & ACS & 44,242 & OR: 3.2 (2.9 to 3.6$)$ & \\
\hline & $\mathrm{ACS}$ and $\mathrm{Hct} \leq 24 \%$ & & aOR: 0.68 (0.45 to 1.02$)$ & \\
\hline & $\mathrm{ACS}$ and $\mathrm{Hct}=24$ to $27 \%$ & & aOR: 1.01 (0.79 to 1.30$)$ & \\
\hline & $\mathrm{ACS}$ and $\mathrm{HCt}=27$ to $30 \%$ & & aOR: 1.18 (0.92 to 1.50$)$ & \\
\hline & ACS and $\mathrm{Hct}>30 \%$ & & aOR: 3.47 (2.30 to 5.23$)$ & \\
\hline \multirow[t]{2}{*}{ Mortality, Aronson, 2008 [36] } & AMI & 2,358 & aHR: $0.13(0.03 \text { to } 0.65)^{\mathrm{d}, \mathrm{e}}$ & 0.013 \\
\hline & & & aHR: $2.2(1.5 \text { to } 3.3)^{\mathrm{d}, \mathrm{f}}$ & $<0.0001$ \\
\hline \multirow[t]{2}{*}{ Mortality, Jani, 2007 [37] } & $\mathrm{AMI}$ & 4,623 & aOR: 2.02 (1.47 to 2.79 ) & $<0.0001$ \\
\hline & & & RR: 4.83 (3.81 to 6.12$)^{d}$ & \\
\hline \multirow[t]{3}{*}{ Mortality, Jolicœur, 2009 [38] } & $\mathrm{AMI}$ & 5,188 & RR: 6.38 (4.88 to 8.34 ) & \\
\hline & & 5,532 & aHR: 2.16 (1.20 to 3.88$)$ & $<0.0001$ \\
\hline & & 5,188 & RR: 6.38 (4.88 to 8.34$)^{d}$ & \\
\hline Mortality, Koch, 2006 [39] & CABG & 5,814 & OR: 1.77 (1.67 to 1.87$)$ & $<0.0001$ \\
\hline Mortality, Murphy, 2007 [40] & Cardiac surgery (UK) & 8,518 & HR: 6.69 (3.66 to 15.1$)$ & $<0.05$ \\
\hline \multirow[t]{2}{*}{ Mortality, Nikolsky, 2009 [41] } & $\mathrm{AMI}$ & 2,060 & HR: 4.71 (1.97 to 11.36$)$ & \\
\hline & & & RR: $2.92(1.62 \text { to } 5.24)^{d}$ & \\
\hline Mortality, Pattakos, 2012 [42] & Cardiac surgery & 644 & $95 \%$ versus $89 \%$ & 0.007 \\
\hline \multirow[t]{2}{*}{ Mortality, Rao, 2004 [43] } & ACS & 24,112 & aHR: 3.94 (3.26 to 4.75$)$ & $<0.05$ \\
\hline & & & RR: $2.60(2.22 \text { to } 3.03)^{d}$ & $<0.05$ \\
\hline Mortality, Shehata, 2012 [19] & CABG & 2,102 & OR: 0.44 (0.32 to 14.1$)$ & NS \\
\hline \multirow[t]{2}{*}{ Mortality, Shishehbor, 2009 [44] } & $\mathrm{AMI}$ & 3,575 & aHR: 3.89 (2.66 to 5.68$)$ & $<0.001$ \\
\hline & & & RR: $1.30(0.90 \text { to } 1.88)^{d}$ & $<0.001$ \\
\hline Mortality, Singla, 2007 [45] & AMI & 370 & RR: $2.36(1.49 \text { to } 3.76)^{d}$ & \\
\hline Mortality, Wu, 2001, [46] & $\mathrm{AMI}$ & 78,974 & RR: $2.51(2.42 \text { to } 2.61)^{\mathrm{d}, \mathrm{g}}$ & $<0.05$ \\
\hline \multirow[t]{2}{*}{ Mortality, Yang, 2005 [47] } & $\mathrm{AMl}$ & 85,111 & aOR: 1.67 (1.48 to 1.88$)$ & $<0.05$ \\
\hline & & & RR: $3.03(2.85 \text { to } 3.21)^{d}$ & $<0.05$ \\
\hline \multicolumn{5}{|l|}{$\begin{array}{l}\text { Outcomes: myocardial infarction or } \\
\text { ischemic events } \mathrm{s}^{\mathrm{h}} \text { in adults }\end{array}$} \\
\hline AMI, Jani, 2007 [37] & AMI & 4,623 & RR: $1.19(0.82 \text { to } 1.74)^{d}$ & \\
\hline AMI, Jolicœur, 2009 [38] & AMl & 5,188 & RR: 3.05 (1.85 to 5.04$)^{d}$ & \\
\hline$I^{h}$, Murphy, 2007 [40] & Cardiac surgery (UK) & 8,518 & aOR: $3.35(2.68 \text { to } 4.35)^{c}$ & $<0.05$ \\
\hline AMI, Nikolsky, 2009 [41] & AMI & 2,060 & RR: $3.28(1.44 \text { to } 7.49)^{d}$ & \\
\hline AMI, Pattakos, 2012 [42] & Cardiac surgery & 644 & $2.8 \%$ versus $0.31 \%$ & $<0.01$ \\
\hline AMI + death, Rao, 2004 [43] & ACS & 2,401 & HR: 3.08 (2.84 to 3.35$)^{d}$ & $<0.05$ \\
\hline AMI, Shishehbor, 2009 [44] & ACS & 3,575 & $\mathrm{aHR}: 3.44$ & $<0.001$ \\
\hline \multirow[t]{2}{*}{ AMI + death, Singla, 2007 [45] } & $\mathrm{AMI}$ & 370 & aOR: 2.57 (1.41 to 4.69$)$ & $<0.001$ \\
\hline & & & RR: 2.10 (0.83 to 5.30$)^{d}$ & \\
\hline AMI, Yang, 2005 [47] & $\mathrm{AMl}$ & 85,111 & aOR: 0.95 (0.83 to 1.09$)^{\mathrm{d}}$ & $<0.05$ \\
\hline Outcomes in children & Health problem & Children & Risk $^{c}$ & $P$-value \\
\hline LMV (days), 2011 [48] & Cardiac surgery & 270 & HR: 0.71 (0.54 to 0.92$)$ & 0.009 \\
\hline LMV (days), 2013 [49] & Cardiac surgery & 335 & HR: 2.6 (2.0 to 3.4$)$ & $<0.001$ \\
\hline
\end{tabular}


Table 2 Red blood cell (RBC) transfusions and outcomes in cardiac patients: observational studies ${ }^{\mathrm{a}}$ (Continued)

\begin{tabular}{|c|c|c|c|c|}
\hline PICU LOS (days), 2013 [49] & Cardiac surgery & 335 & LOS: $8 \pm 0.9$ versus $3.5 \pm 2$ & $<0.001$ \\
\hline Hospital LOS, 2011 [24] & Cardiac surgery & 802 & aHR: 0.65 (0.49 to 0.87 ) & $<0.001$ \\
\hline Wound infection, 2010 [50] & Cardiac surgery & 216 & aOR: 7.87 (1.63 to 37.92$)$ & $<0.001$ \\
\hline
\end{tabular}

ACS: acute coronary syndrome; aHR: adjusted HR; AMI: acute myocardial infarction; aOR: adjusted OR; CABG: coronary artery bypass graft; card surg: cardiac surgery; Cl: confidence interval; Hct: hematocrit; HR: hazard ratio; IE: ischemic events; LMV: length of MV; LOS: length of stay; MI: myocardial infarction; MV: mechanical ventilation; OR: odds ratio; PICU: pediatric intensive care unit; RBC: red blood cell; NS: not significant; RCT: randomized controlled trial; UK: United Kingdom.

${ }^{a}$ Studies on the relationship between the length of storage of RBC units and outcomes of transfused cardiac patients are excluded from this table.

${ }^{b}$ Year of publication.

${ }^{\mathrm{C}}$ Transfused patients versus no RBC transfusion or restricted RBC transfusion strategy.

${ }^{\mathrm{d}}$ Chatterjee et al. [51] completed a systematic review that included the studies marked by ${ }^{\mathrm{d}}$ in this table, plus a small RCT conducted by Cooper et al. [52]. Overall, the risk ratio of death in transfused patients versus controls was 2.91 (95\% confidence interval (Cl): 2.46 to 3.44$)$, but there was a very significant heterogeneity $\left(I^{2}=92 \%\right)$.

ePre-transfusion hemoglobin concentration $\leq 80 \mathrm{~g} / \mathrm{L}$.

${ }^{f}$ Pre-transfusion hemoglobin concentration $>80 \mathrm{~g} / \mathrm{L}$.

${ }^{9}$ The study by Wu et al. [46] enrolled patients $\geq 65$ years of age with AMI. RBC transfusion was associated with a reduction in 30 -day mortality if hematocrit $<24 \%$ $(\mathrm{aOR}=0.22 ; 95 \% \mathrm{Cl}: 0.11$ to 0.45 ) or between $30 \%$ and $33 \%(\mathrm{aOR}=0.69 ; 95 \% \mathrm{Cl}: 0.53$ to 0.89 ), but the risk of mortality was not increased in patients with a hematocrit $>33 \%$ who received $\mathrm{RBC}$ transfusion

hIschemic events: myocardial infarction, stroke, renal impairment, or failure.

of mortality in 2,102 adults who were transfused after coronary artery bypass graft (CABG), but the association was not statistically significant (adjusted OR $(\mathrm{aOR})=0.44 ; 95 \%$ CI: 0.32 to 14.1 ).

On the other hand, six studies of adults undergoing cardiac surgery, CABG or with myocardial infarction reported increased mortality in transfused cardiac patients [39,40,42-44,47]. Rao et al. [43] published a descriptive epidemiological study on 24,112 patients with acute coronary syndrome who were enrolled in three large randomized controlled trials (RCTs). They compared the outcomes of those who received at least one RBC transfusion $(n=21,711)$ and those who did not $(n=2,401)$; $\mathrm{RBC}$ transfusion was associated with an increased HR for 30-day mortality ( $\mathrm{HR}=3.94 ; 95 \% \mathrm{CI}$ : 3.26 to 4.75$)$. Probability of 30-day mortality was higher in transfused patients with nadir hematocrit values above $25 \%$. In the systematic review of Chatterjee et al. [51], the risk ratio of death in transfused patients versus controls was 2.91 (95\% CI: 2.46 to 3.44 ) and the risk of secondary myocardial infarction was 2.04 (95\% CI: 1.06 to 3.93), but there was a very significant heterogeneity in both instances ( $I^{2}: 92 \%$ and 98\% respectively). Garfinkle et al. [53] also published a systematic review on 11 observational studies that enrolled 290,847 patients with acute coronary syndrome: the unadjusted OR of mortality in transfused patients ranged from 1.9 to 11.2 ; a meta-analysis was not performed because there was too much heterogeneity, but the data suggested a protective effect of $\mathrm{RBC}$ transfusion if nadir $\mathrm{Hb}$ drops below $80 \mathrm{~g} / \mathrm{L}$ and neutral or harmful effects above $110 \mathrm{~g} / \mathrm{L}$. In summary, there is evidence in adults with cardiac disease that RBC transfusion is associated with mortality and ischemic events.

\section{Pediatric cardiac patients}

There is less evidence in children. Three studies reported prolonged length of mechanical ventilation in children who received RBC transfusion after cardiac surgery [48,49,54], three reported prolonged length of PICU and/or hospital stay $[24,49,54]$ and three reported an increased incidence of infections [33,50,54]. In 657 consecutive children undergoing open heart surgery, Székely et al. [33] found an association between total volume of blood transfusion and the rate of infections (aOR: 1.01; 95\% CI: 1.002 to 1.02, $P<0.01$ ), but no association with mortality (aOR: 1.00; 95\% CI: 0.99 to $1.02, P=0.65)$.

\section{Risks/benefits of RBC transfusions: summary}

Is it justified to prescribe more $\mathrm{RBC}$ transfusions to cardiac than to non-cardiac ICU patients? The available data on this question are inconclusive: while some descriptive studies suggest a benefit to transfusion, most studies associate $\mathrm{RBC}$ transfusion to worse outcomes. Descriptive studies cannot prove that there is a cause-effect relationship between a risk factor and a given outcome: adjustment for confounders like volume of RBC transfusion and administration of other blood products can be done, but a possibility always remains that unknown confounders play a role. Moreover, severity of illness is associated with both transfusion and mortality $[8,24]$. A multivariate analysis cannot deconstruct such confounding by indication [55]; only RCTs can [56].

\section{Transfusion related adverse events}

The safety of blood products with respect to transfusiontransmitted infectious diseases has improved greatly in recent decades. Presently, the greatest concern is noninfectious serious hazards of transfusion (NISHOT) [57-59].

NISHOT may be non-immune or immune-mediated. Short-term non-immune NISHOT include transfusionrelated circulatory overload (TACO) and overtransfusion. Overtransfusion is of concern because of the risk of TACO and/or hyperviscosity. Viscous blood flow may impair $\mathrm{DO}_{2}$ in small vessels and decrease coronary 
blood flow. Barr et al. [60] reviewed the data of 1,474 transfused patients: $19 \%$ of them were overtransfused according to the British RBC transfusion guidelines. Sabatine et al. [61] reported an increased mortality in patients with ST-elevation myocardial infarction when $\mathrm{Hb}$ value was $>170 \mathrm{~g} / \mathrm{L}(\mathrm{OR}=1.79 ; 95 \% \mathrm{CI}: 1.18$ to 2.71 , $P=0.007)$ and $>160 \mathrm{~g} / \mathrm{L}(\mathrm{OR}=1.31 ; 95 \% \mathrm{CI}: 1.03$ to $1.66, P=0.027)$ in patients with non-ST-elevation myocardial infarction.

Immune-mediated NISHOT include hemolytic and allergic reactions, transfusion-related immunomodulation (TRIM), transfusion-related acute lung injury (TRALI), nosocomial infections, transfusion-associated graft versus host disease, and alloimmunization to RBC and HLA antigens $[57,62,63]$.

In critically ill cardiac patients, TRIM may represent a significant 'second-hit' when added to pre-existing organ dysfunction and/or a systemic inflammatory response syndrome (SIRS), which may result in TRALI and multiple organ dysfunction syndrome. Vlaar et al. [64] reported that in cardiac surgery patients, RBC transfusion was associated with an increase pulmonary leak index, an early marker of acute lung injury. Inflammatory markers in bronchoalveolar lavage were increased in transfused cardiac surgery patients when compared to controls [65]. TRALI may be an important underdiagnosed cause of lung injury in cardiac and noncardiac ICU patients $[66,67]$.

Although NISHOT are currently the most important causes of transfusion-related fatalities, their incidence rate in cardiac patients is not well characterized [58].

\section{Restrictive or liberal RBC transfusion strategy}

As illustrated in Figure 1, the relationship between $\mathrm{DO}_{2}$ and $\mathrm{O}_{2}$ consumption $\left(\mathrm{VO}_{2}\right)$ remains horizontal as long as compensatory mechanisms (increasing cardiac output and $\mathrm{O}_{2}$ extraction) are still effective $[10,68]$. However, $\mathrm{VO}_{2}$ drops with $\mathrm{DO}_{2}$ below a critical threshold. Anemia decreases $\mathrm{DO}_{2}$ and it is unmistakably deleterious below a certain threshold. The critical Hb level threshold below which $\mathrm{DO}_{2}$ becomes significantly impaired and transfusion becomes less harmful than persisting anemia is unknown and likely varies depending upon the underlying condition and clinical status of each patient. Anemia is well endured by healthy subjects: acute isovolemic reduction of $\mathrm{Hb}$ level down to $50 \mathrm{~g} / \mathrm{L}$ was hemodynamically well tolerated by 11 resting healthy humans [69], but delayed memory was observed in 31 healthy young volunteers after a similar reduction of $\mathrm{Hb}$ [70]. However, cardiac patients may have higher thresholds of critical $\mathrm{DO}_{2}$ than healthy adults and target $\mathrm{Hb}$ for transfusion might be different (Figures 1 and 2). Moreover, patients with cardiac disease may also be more vulnerable than the general population to adverse effects of transfusion (disturbed rheology [71] and coagulation [65], NISHOT [57], dysfunctional vasoregulation [72], circulatory overload, and so on).

Confronted with the risks of transfusion and a growing body of literature associating RBC transfusion with adverse outcomes, a number of RCTs have now compared the safety of adopting a restrictive versus liberal $\mathrm{RBC}$ transfusion strategy (low versus higher threshold $\mathrm{Hb}$ ) in critically ill patients with cardiac disease (Table 3 ).

Table 3 Restrictive versus liberal red blood cell $(\mathrm{RBC})$ transfusion strategy in cardiac patients: randomized clinical trials

\begin{tabular}{|c|c|c|c|c|}
\hline First author, year ${ }^{a}$ & Health problem & $\begin{array}{l}\text { Patients } \\
\text { (n) }\end{array}$ & $\begin{array}{l}\text { Mortality } \\
(95 \% \mathrm{Cl})\end{array}$ & $P$-value \\
\hline \multicolumn{5}{|l|}{ Adults } \\
\hline Bracey, 1999 [73] & CABG & 428 & RR: 0.52 (0.13 to 2.04) & NS \\
\hline Carson, 2011 [74] & Hip surgery ${ }^{c}$ & 2,016 & ARR: $0.9(-1.5$ to +3.4$)$ & NS \\
\hline Cooper, 2001 [52] & Myocardial infarction & 46 & $8 \%$ versus $5 \%$ & 1.0 \\
\hline Hajjar, 2012 [23] & Cardiac surgery & 502 & $6 \%$ versus $5 \%$ & 0.93 \\
\hline Hébert, 2001 [75] & ICU cardiac patients & 357 & $22.5 \%$ versus $22.7 \%$ & 1.00 \\
\hline Johnson, 1992 [76] & CABG & 38 & No difference ${ }^{d}$ & NS \\
\hline Shehata, 2012 [19] & Cardiac surgery & 50 & $16 \%$ versus $4 \%$ & NS \\
\hline \multicolumn{5}{|l|}{ Pediatric cardiac surgery } \\
\hline Cholette, 2011 [77] & Cyanotic & 60 & 1 death & NS \\
\hline de Gast-Bakker, 2013 [78] & Non-cyanotic & 107 & No death & NS \\
\hline Willems, 2010 [79] & Non-cyanotic & 125 & $12.7 \%$ versus $6.5 \%$ & 0.36 \\
\hline
\end{tabular}

ARR: absolute risk reduction; CABG: coronary artery bypass graft; $\mathrm{Cl}$ : confidence interval; RBC: red blood cell; NS: not statistically significant.

${ }^{\mathrm{a}}$ Year of publication.

${ }^{\mathrm{b}}$ Restrictive versus liberal transfusion strategy.

${ }^{c}$ Hip surgery in patients older than 50 years with atherosclerosis.

${ }^{\mathrm{d}}$ No significant difference in duration or degree of exercise was demonstrated between the two groups. 


\section{RBC transfusion strategy in cardiac adults}

We found seven RCTs conducted in adults with cardiac illness [19,23,52,73-76]; all enrolled only hemodynamically stable patients. All but one [23] reported that a restrictive strategy was as safe or safer than a liberal strategy. Three RCTs included more than 50 patients.

In 1999, Hébert et al. [80] published the 'Transfusion Requirements in Critical Care' (TRICC) study. Euvolemic patients were randomized to receive a RBC transfusion if $\mathrm{Hb}$ level was below $100 \mathrm{~g} / \mathrm{L}$ (liberal strategy) or below 70 $\mathrm{g} / \mathrm{L}$ (restrictive strategy). Patients with acute myocardial infarction and unstable angina were excluded. A subgroup analysis of 357 patients with cardiovascular disease was published in 2001 [75]; the 30-day all-cause mortality was similar $(22.5 \%$ versus $22.7 \%, P=1.00)$.

Hajjar et al. [23] published a single center non-inferiority RCT of 502 adults undergoing cardiac surgery who were allocated to receive a transfusion if hematocrit was below $24 \%$ or $30 \%$. The pre-transfusion $\mathrm{Hb}$ level was 91 in the restrictive and $105 \mathrm{~g} / \mathrm{L}$ in the liberal group. They found a similar incidence of 30-day all-cause mortality (6\% in the restrictive and $5 \%$ in the liberal group, $P=0.93$ ), cardiogenic shock ( $5 \%$ versus $9 \%, P=0.42)$, acute respiratory distress syndrome ( $1 \%$ versus $2 \%, P=0.99)$ and acute renal failure ( $5 \%$ versus $4 \%, P=0.99$ ). The number of $\mathrm{RBC}$ units transfused was independently associated with 30-day all-cause mortality (HR $=1.2 /$ unit; $95 \% \mathrm{CI}$ : 1.1 to 1.4, $P=0.002)$.

Carson et al. [74] published the 'Functional Outcomes in Cardiovascular Patients Undergoing Surgical Hip Fracture Repair' (FOCUS) study, a large multicenter RCT of 2,016 adults over 50 years of age with known atherosclerotic disease undergoing a hip surgery and who had a $\mathrm{Hb}$ level below $100 \mathrm{~g} / \mathrm{L}$ within 3 days post-surgery. The restrictive group was transfused if $\mathrm{Hb}$ level fell below $80 \mathrm{~g} / \mathrm{L}$, the liberal group if below $100 \mathrm{~g} / \mathrm{L}$. Primary outcome was ability to walk 10 feet unassisted or death 60 days postrandomization. No difference was found in any of the outcomes, including survival, postoperative complications, activities of daily living and disposition.

In summary, the available RCTs suggest that a restrictive transfusion strategy (threshold $\mathrm{Hb}$ level for transfusion: 70 or $80 \mathrm{~g} / \mathrm{L}$ ) appears as safe as a liberal strategy in stable adult ICU patients with cardiac disease.

\section{RBC transfusion strategy in cardiac children}

Three RCTs compared a restrictive and a liberal transfusion strategy after pediatric cardiac surgery.

In the 'Transfusion Requirements In PICU' (TRIPICU) study [81], 637 stabilized critically ill children were randomized to receive a RBC transfusion if their Hb dropped below 70 or $95 \mathrm{~g} / \mathrm{L}$ [81]. Patients were considered stable if mean systemic arterial pressure was not less than two standard deviations below the normal mean for age and if cardiovascular treatment (fluids and/or medication) had not been increased for at least two hours before enrollment. Children with cyanotic cardiac disease and neonates under 28 days were excluded. A sub-group analysis of 125 cardiac children enrolled in TRIPICU demonstrated no significant difference in new or progressive multiple organ dysfunction syndrome (restrictive versus liberal group: $12.7 \%$ versus $6.5 \%, P=0.36)$, PICU length of stay $(7.0 \pm 5.0$ versus $7.4 \pm 6.4$ days) or 28 -day mortality (3.2\% versus 3.2\%) [79].

An RCT compared the outcome of cardiac children older than 6 weeks randomized to receive a RBC transfusion if $\mathrm{Hb}$ level dropped below $80 \mathrm{~g} / \mathrm{L}$ or $108 \mathrm{~g} / \mathrm{L}$ [78]. Patients with cyanotic cardiac disease were excluded. Randomization occurred before surgery; the research protocol with respect to $\mathrm{RBC}$ transfusion was initiated in the operating room and maintained up to PICU discharge. One hundred patients were enrolled and retained for analysis. Duration of mechanical ventilation, length of PICU stay and incidence of adverse events were similar in both groups, but length of hospital stay was shorter in the restrictive group (median: 8 interquartile range: 7 to 11 \} versus $9\{7$ to 14$\}$ days, $P=0.063$ ).

Physicians target higher $\mathrm{Hb}$ values for critically ill children with cyanotic heart disease [28,29]. In an RCT completed by Cholette et al. [77], 60 children were randomized after Glenn or Fontan palliation to a restrictive (transfusion if $\mathrm{Hb}<90 \mathrm{~g} / \mathrm{L}$ ) or liberal group $(<130 \mathrm{~g} / \mathrm{L})$. One death was observed (liberal group). There was no difference in mean and peak arterial lactate, arteriovenous and arterio-cerebral oxygen content. Although not powered to demonstrate statistical significance, mortality, PICU and hospital length of stay, duration of mechanical ventilation, dose and duration of inotropic support were similar.

\section{Goal-directed transfusion therapy}

Goal-directed RBC transfusion therapy targeting a physiological goal may be a more appropriate target than specific $\mathrm{Hb}$ levels. The concept of goal-directed therapy is well illustrated by the RCT conducted by Rivers et al. [82]: 266 adults with severe sepsis or septic shock were randomized to be monitored or not with $\mathrm{ScvO}_{2}$. Patients allocated to $\mathrm{ScrO}_{2}$ monitoring were also assigned to a bundle of treatment to maintain their $\mathrm{ScvO}_{2}$ over 70\%; this bundle included, in sequential order, mechanical ventilation, fluid bolus, vasoactive drugs and RBC transfusion if the $\mathrm{ScvO}_{2}$ remained under 70\% after all other interventions. Mortality was $30.5 \%$ with goal-directed therapy versus $46.5 \%$ in controls.

There are currently no hard data on goal-directed transfusion therapy in cardiac patients. Goals that can be considered include physiologic parameters like $\mathrm{DO}_{2}$ measured by a Swan-Ganz catheter or locally with near infrared 
spectroscopy (NIRS), global oxygen consumption $\left(\mathrm{VO}_{2}\right)$, blood lactate, mixed venous $\mathrm{O}_{2}$ saturation $\left(\mathrm{Sv}^{\prime} \mathrm{O}_{2}\right), \mathrm{ScvO}_{2}$, tissue $\mathrm{O}_{2}$ saturation and $\mathrm{O}_{2}$ extraction rate [10]. Wellconducted research is required to demonstrate the reliability and clinical applicability of a test before we start to use it at the bedside. There are examples of tests that were too rapidly adopted by the medical community. For example, regional (splanchnic and/or renal) NIRS is frequently used to detect low cardiac output in ICU patients; a recent study showed that its positive predictive value is so low that it cannot be considered a reliable test [83]. Repeated ('dynamic') measurements of NIRS might be more informative than 'static' measures [84], but this remains to be proven. Transfusion therapy guided by $\mathrm{ScvO}_{2}$ is another candidate. The results of the trial by Rivers et al. [82] suggested that RBC transfusion might be useful in septic patients. Another RCT conducted in 102 children with severe sepsis or fluid refractory shock reported similar results (mortality: $11.8 \%$ versus $39.2 \%$ in controls) [85]. However, in the ProCESS three arms RCT [86], 1,341 adults were allocated to a protocol-based goal-directed therapy that required the placement of a central venous catheter, a protocol-based standard therapy without such catheter, or usual care; no difference was observed in any outcomes, which questions the results of the RCTs by Rivers and de Oliveira $[82,85]$. Moreover, the specific contribution of RBC transfusions was unclear in these RCTs and none enrolled cardiac patients.

Currently, we do not know what physiologic parameters we must use to guide a goal-directed transfusion therapy in cardiac patients. Further clinical studies are required before a given goal that would help practitioners to precisely decide when to transfuse cardiac patients can be recommended in this population.

\section{Conclusion}

Anemia is common in patients with cardiac disease and is associated with mortality and morbidity. RBC transfusion is the best way to rapidly increase the $\mathrm{Hb}$ level, but it is not risk-free: storage lesion and NISHOT, including prothrombotic and proinflammatory effects, may cause transfusion-related adverse events.

The $\mathrm{Hb}$ level at which the risk of anemia outweighs the risk of transfusion is not well known. Three observational studies suggest that there might be some benefit to give a RBC transfusion to adults with acute coronary syndrome if their $\mathrm{Hb}$ level is $<80 \mathrm{~g} / \mathrm{L}$, but many more studies suggest that $\mathrm{RBC}$ transfusion might be harmful in this population if their $\mathrm{Hb}$ level is higher than 80 to $100 \mathrm{~g} / \mathrm{L}$. The question of RBC transfusion to adults with acute coronary syndrome is not addressed in the guidelines of the American College of Cardiology, the American Heart Association and the Canadian Cardiovascular Society [87]. However, a number of RCTs in hemodynamically stable cardiac patients suggest a level of $\mathrm{Hb}$ (about $80 \mathrm{~g} / \mathrm{L}$ ) above which it appears safe not to transfuse, thereby avoiding the risks related to transfusions.

Data in children are scarce. In stable acyanotic cardiac children, a Hb level above 70 or $80 \mathrm{~g} / \mathrm{L}$ appears to be well tolerated without RBC transfusion. In children with cyanotic heart lesions, $\mathrm{Hb}$ level over $90 \mathrm{~g} / \mathrm{L}$ appears safe. The threshold $\mathrm{Hb}$ level for unstable cardiac children and for neonates is unknown. Goal-directed transfusion therapy is a promising avenue for future research.

Severity of illness, anemia and transfusions are interconnected with outcome in cardiac patients, and their individual contribution to outcome remains unresolved. Further RCTs are necessary to disentangle this relationship.

\section{Abbreviations}

ACS: acute coronary syndrome; aHR: adjusted HR; AMI: acute myocardial infarction; aOR: adjusted OR; APACHE: acute physiology and chronic health; CABG: coronary artery bypass graft; $\mathrm{Cl}$ : confidence interval; $\mathrm{DO}_{2}: \mathrm{O}_{2}$ delivery; $\mathrm{Hb}$ : hemoglobin; Hct: hematocrit; ICU: intensive care unit; IE: ischemic events; HR: hazard ratio; MI: myocardial infarction; MODS: multiple organ dysfunction syndrome; MV: mechanical ventilation; NIRS: near infrared spectroscopy; NISHOT: non-infectious serious hazard of transfusion; OR: odds ratio;

PCI: percutaneous coronary intervention; PICU: pediatric ICU; PRISM: pediatric risk of mortality; RBC: red blood cell; RCT: randomized controlled trial;

RR: relative risk; $\mathrm{ScvO}_{2}$ : central venous $\mathrm{O}_{2}$ saturation; $\mathrm{Sv}^{\prime} \mathrm{O}_{2}$ : mixed venous $\mathrm{O}_{2}$ saturation; TACO: transfusion-associated circulatory overload;

TRALI: transfusion-related acute lung injury; TRIM: transfusion-related immunomodulation; $\mathrm{VO}_{2}: \mathrm{O}_{2}$ consumption.

\section{Competing interest}

The authors declare that they have no competing interests.

\section{Authors' contribution}

$\mathrm{GD}, \mathrm{KH}$ and $J$ wrote, revised and approved the manuscript in its final form.

\section{Source of funding}

Supported by the Fonds de la Recherche en Santé du Québec (grant \#24460) and by the Groupe de Recherche en Transfusion Sanguine (http://www. chu-sainte-justine.org/recherche).

Received: 15 January 2014 Accepted: 7 May 2014

Published: 2 June 2014

\section{References}

1. For the ABC Investigators, Vincent JL, Baron JF, Reinhart K, Gattinoni L, Thijs L, Webb A, Meier-Hellmann A, Nollet G: Anemia and blood transfusion in critically ill patients. JAMA 2002, 288:1499-1507.

2. Corwin HL, Gettinger A, Pearl RG, Fink MP, Levy MM, Abraham E, Maclntyre NR, Shabot MM, Duh MS, Shapiro MJ: The CRIT Study: anemia and blood transfusion in the critically ill - current clinical practice in the United States. Crit Care Med 2004, 32:39-52.

3. Bateman ST, Lacroix J, Boven K, Forbes P, Barton R, Thomas N, Jacobs B, Markovitz B, Goldstein B, Hanson J, Randolph AG, for the Pediatric Acute Lung Injury and Sepsis Investigator's (PALISI) Network: Anemia, blood loss and blood transfusion in North American children in the intensive care unit. Am J Respir Crit Care Med 2008, 178:26-33.

4. Tinmouth A, Fergusson D, Chin-Yee I, Hebert PC: Clinical consequences of red cell storage in the critically ill. Transfusion 2006, 46:2014-2027.

5. Lacroix J, Hébert PC, Fergusson D, Tinmouth A, Blajchman MA, Callum J, Cook D, Marshall J, Mclntyre L, Turgeon A, for the ABLE study group, and the Canadian Critical Care Trials Group: The age of blood evaluation (ABLE) randomized controlled trial: study design. Transfus Med Rev 2011, 25:197-205.

6. Lacroix J, Tucci M: Impact clinique de la durée d'entreposage des globules rouges avant transfusion. Transfus Clin Biol 2011, 18:97-105. 
7. Aubrun C, Nichol A, Cooper DJ, Bellomo R: Age of red blood cells and transfusion in critically ill patients. Ann Intensive Care 2013, 3:2

8. Reed SD, Li Y, Ellis SJ, Isitt JJ, Cheng S, Schulman KA, Whellan DJ: Associations between hemoglobin level, resource use, and medical costs in patients with heart failure: findings from HF-ACTION. J Card Fail 2012, 18:784-791.

9. Lawler PR, Filion KB, Dourian T, Atallah R, Garfinkle M, Eisenberg MJ: Anemia and mortality in acute coronary syndromes: a systematic review and meta-analysis. Am Heart J 2013, 165:143-153.

10. Vallet $B$, Robin $E$, Lebuffe $G$ : Venous oxygen saturation as a physiologic transfusion trigger. Crit Care 2010, 14:213.

11. Spahn DR, Smith LR, Schell RM, Hoffman RD, Gillespie R, Leone BJ: Importance of severity of coronary artery disease for the tolerance to normovolemic hemodilution. Comparison of single-vessel versus multivessel stenoses in a canine model. J Thorac Cardiovasc Surg 1994, 108:231-239.

12. Spahn DR, Smith LR, Veronee CD, MCRae RL, Hu WC, Menius AJ, Lowe JE, Leone BJ: Acute isovolemic hemodilution and blood transfusion. Effects on regional function and metabolism in myocardium with compromised coronary blood flow. J Thorac Cardiovasc Surg 1993, 105:694-704.

13. Carson JL, Duff A, Poses RM, Berlin JA, Spence RK, Trout R, Noveck H, Strom BL: Effect of anaemia and cardiovascular disease on surgical mortality and morbidity. Lancet 1996, 348:1055-1060.

14. Liu Y, Yang YM, Zhu J, Tan HQ, Liang Y, Li JD: Anaemia and prognosis in acute coronary syndrome: a systematic review and meta-analysis. J Int Med Res 2012, 40:43-55.

15. Ezekowitz JA, McAlister FA, Armstrong PW: Anemia is common in heart failure and is associated with poor outcomes: insights from a cohort of 12,065 patients with new-onset heart failure. Circulation 2003, 107:223-225.

16. Lee PC, Kini AS, Ahsan C, Fisher E, Sharma SK: Anemia is an independent predictor of mortality after percutaneous coronary intervention. J Am Coll Cardiol 2004, 44:541-546.

17. McKechnie RS, Smith D, Montoye C, Kline-Rogers E, O'Donnell MJ, DeFranco AC, Meengs WL, McNamara R, McGinnity JG, Patel K, Share D, Riba A, Khanal S, Moscucci M, Blue Cross Blue Shield of Michigan Cardiovascular Consortium (BMC2): Prognostic implication of anemia on in-hospital outcomes after percutaneous coronary intervention. Circulation 2004, 110:271-277.

18. Ranucci M, Di Dedda U, Castelvecchio S, Menicanti L, Frigiola A, Pelissero G: Surgical and Clinical Outcome Research (SCORE) Group. Impact of preoperative anemia on outcome in adult cardiac surgery: a propensity-matched analysis. Ann Thorac Surg 2012, 94:1134-1141.

19. Shehata N, Burns LA, Nathan H, Hebert P, Hare GM, Fergusson D, Mazer CD: A randomized controlled pilot study of adherence to transfusion strategies in cardiac surgery. Transfusion 2012, 52:91-99.

20. Sulaiman K, Prashanth P, Al-Zakwani I, Al-Mahmeed W, Al-Motarreb A, Al Suwaidi J, Amin H, Asaad N, Hersi A, Al Faleh H, Al Saif S, Alsheik-Ali AA Al LJ, Al-Habib K: Impact of anemia on in-hospital, one-month and one-year mortality in patients with acute coronary syndrome from the Middle East. Clin Med Res 2012, 10:65-71.

21. Kammache I, Parrinello G, Marini D, Bonnet D, Agnoletti G: Anaemia is a predictor of early death or cardiac transplantation in children with idiopathic dilated cardiomyopathy. Cardiol Young 2012, 22:293-300.

22. Bennett-Guerrero E, Zhao Y, O'Brien SM, Ferguson TB, Peterson ED, Gammie JS, Song HK: Variation in use of blood transfusion in coronary artery bypass graft surgery. JAMA 2010, 304:1568-1575.

23. Hajjar LA, Vincent $J$, Galas FR, Nakamura RE, Silva CM, Santos MH, Fukushima J, Kalil Filho R, Sierra DB, Lopes NH, Mauad T, Roquim AC, Sundin MR, Leão WC, Almeida JP, Pomerantzeff PM, Dallan LO, Jatene FB, Stolf NA, Auler JO Jr: Transfusion requirements after cardiac surgery: the TRACS randomized controlled trial. JAMA 2010, 304:1559-1567.

24. Salvin JW, Scheurer MA, Laussen PC, Wypij D, Polito A, Bacha EA, Pigula FA McGowan FX, Costello JM, Thiagarajan RR: Blood transfusion after pediatric cardiac surgery is associated with prolonged hospital stay. Ann Thorac Surg 2011, 91:204-210.

25. Chambers LA, Cohen DM, Davis JT: Transfusion patterns in pediatric open heart surgery. Transfusion 1996, 36:150-156.

26. Armano R, Gauvin F, Ducruet T, Hume H, Lacroix J: Determinants of red blood cell transfusions in a pediatric critical care unit: a prospective descriptive epidemiological study. Crit Care Med 2005, 33:2637-2644.

27. Keung CY, Smith KR, Savoia HF, Davidson AJ: An audit of transfusion of red blood cell units in pediatric anesthesia. Pediatr Anesth 2009, 19:320-328.
28. Demaret P, Tucci T, Ducruet T, Trottier H, Lacroix J: Red blood cell transfusion in critically ill children. Transfusion 2014, 54:365-375.

29. Harrington K, Farrell C, Poirier N, Ducruet T, Lacroix J: Survey on red-cell transfusion practices after paediatric cardiac surgery. Pediatr Crit Care Med 2011, 12:A82.

30. For the Transfusion Requirements in Critical Care Investigators, Hébert PC, Wells G, Martin C, Tweeddale M, Marshall J, Blajchman M, Pagliarello G, Schweitzer I, Calder L: A Canadian survey of transfusion practices in critically ill patients. Crit Care Med 1998, 26:482-487.

31. Laverdière C, Gauvin F, Hébert PC, Infante-Rivard C, Hume H, Toledano BJ, Lacroix J: Survey of transfusion practices in pediatric intensive care units. Pediatr Crit Care Med 2002, 3:335-340.

32. Nahum E, Ben-Ari J, Schonfeld T: Blood transfusion policy among European pediatric intensive care physicians. I Intensive Care Med 2004, 19:38-43.

33. Székely A, Cserép Z, Sápi E, Breuer T, Nagy CA, Vargha P, Hartyánszky I, Szatmári A, Treszl A: Risks and predictors of blood transfusion in pediatric patients undergoing open heart operations. Ann Thorac Surg 2009, 87:187-197

34. Lackritz EM, Hightower AW, Zucker JR, Ruebush TK, Onudi CO, Steketee RW, Were JB, Patrick E, Campbell CC: Longitudinal evaluation of severely anemic children in Kenya: The effect of transfusion on mortality and hematologic recovery. AIDS 1997, 11:1487-1494

35. Alexander KP, Chen AY, Wang TY, Rao SV, Newby LK, LaPointe NM, Ohman EM, Roe MT, Boden WE, Harrington RA, Peterson ED, CRUSADE Investigators: Transfusion practice and outcomes in non-ST-segment elevation acute coronary syndromes. Am Heart J 2008, 155:1047-1053.

36. Aronson D, Dann EJ, Bonstein L, Blich M, Kapeliovich M, Beyar R, Markiewicz W, Hammerman H: Impact of red blood cell transfusion on clinical outcomes in patients with acute myocardial infarction. Am J Cardiol 2008, 102:115-119.

37. Jani SM, Smith DE, Share D, Kline-Rogers E, Khanal S, O'Donnell MJ, Gardin J, Moscucci M: Blood transfusion and in-hospital outcomes in anemic patients with myocardial infarction undergoing percutaneous coronary intervention. Clin Cardio/ 2007, 30(Suppl 2):\|49-||56.

38. Jolicoeur EM, O'Neill WW, Hellkamp A, Hamm CW, Holmes DR, Al-Khalidi HR, Patel MR, Van de Werf FJ, Pieper K, Armstrong PW, Armstrong PW, Granger CB, APEX-AMI Investigators: Transfusion and mortality in patients with ST-segment elevation myocardial infarction treated with primary percutaneous coronary intervention. Eur Heart J 2009, 30:2575-2583.

39. Koch CG, Li L, Duncan Al, Mihaljevic T, Cosgrove DM, Loop FD, Starr NJ, Blackstone EH: Morbidity and mortality risk associated with red blood cell and blood-component transfusion in isolated coronary artery bypass grafting. Crit Care Med 2006, 34:1608-1616.

40. Murphy GJ, Reeves BC, Rogers CA, Rizvi SI, Culliford L, Angelini GD: Increased mortality, postoperative morbidity, and cost after red blood cell transfusion in patients having cardiac surgery. Circulation 2007, 116:2544-2552.

41. Nikolsky E, Mehran R, Sadeghi HM, Grines CL, Cox DA, Garcia E, Tcheng JE, Griffin JJ, Guagliumi G, Stuckey T, Turco M, Fahy M, Lansky AJ, Stone GW: Prognostic impact of blood transfusion after primary angioplasty for acute myocardial infarction: analysis from the CADILLAC (Controlled Abciximab and Device Investigation to Lower Late Angioplasty Complications) Trial. JACC Cardiovasc Interv 2009, 2:624-632.

42. Pattakos G, Koch CG, Brizzio ME, Batizy LH, Sabik JF, Blackstone EH, Lauer MS: Outcome of patients who refuse transfusion after cardiac surgery: A natural experiment with severe blood conservation. Arch Intern Med 2012, 172:1154-1160.

43. Rao SV, Jollis JG, Harrington RA, Granger CB, Newby LK, Armstrong PW Moliterno DJ, Lindblad L, Pieper K, Topol EJ, Stamler JS, Califf RM: Relationship of blood transfusion and clinical outcomes in patients with acute coronary syndromes. JAMA 2004, 292:1555-1562.

44. Shishehbor MH, Madhwal S, Rajagopal V, Hsu A, Kelly P, Gurm HS, Kapadia SR, Lauer MS, Topol EJ: Impact of blood transfusion on short- and long-term mortality in patients with ST-segment elevation myocardial 639 infarction. J Am Coll Cardiol Intv 2009, 2:46-53.

45. Singla I, Zahid M, Good CB, Macioce A, Sonel AF: Impact of blood transfusions in patients presenting with anemia and suspected acute coronary syndrome. Am J Cardiol 2007, 99:1119-1121.

46. Wu WC, Rathore SS, Wang Y, Radford MJ, Krumholz HM: Blood transfusion in elderly patients with acute myocardial infarction. N Engl J Med 2001, 345:1230-1236. 
47. Yang X, Alexander KP, Chen AY, Roe MT, Brindis RG, Rao SV, Gibler WB, Ohman EM, Peterson ED, CRUSADE Investigators: The implications of blood transfusions for patients with non-ST-segment elevation acute coronary syndromes: results from the CRUSADE National Quality Improvement Initiative. J Am Coll Cardiol 2005, 46:1490-1495.

48. Kipps AK, Wypij D, Thiagarajan RR, Bacha EA, Newburger JW: Blood transfusion is associated with prolonged duration of mechanical ventilation in infants undergoing reparative cardiac surgery. Pediatr Crit Care Med 2011, 12:52-56.

49. Kneyber MCJ, Grotenhuis F, Berger RFM, Ebels TW, Burgerhof JGM, Albers MJJJ: Transfusion of leukocyte-depleted red blood cells is independently associated with increased morbidity after pediatric cardiac surgery. Pediatr Crit Care Med 2013, 14:298-305.

50. Costello JM, Graham DA, Morrow DF, Morrow J, Potter-Bynoe G, Sandora TJ, Pigula FA, Laussen PC: Risk factors for surgical site infection after cardiac surgery in children. Ann Thorac Surg 2010, 89:1833-1834

51. Chatterjee S, Wetterslev J, Sharma A, Lichstein E, Mukherjee D: Association of blood transfusion with increased mortality in myocardial infarction. Arch Intern Med 2013, 172:132-139.

52. Cooper HA, Rao SV, Greenberg MD, Rumsey MP, McKenzie M, Alcorn KW Panza JA: Conservative versus liberal red cell transfusion in acute myocardial infarction (the CRIT Randomized Pilot Study). Am J Cardiol 2011, 108:1108-1111.

53. Garfinkle M, Lawler PR, Filion KB, Eisenberg MJ: Red blood cell transfusion and mortality among patients hospitalized for acute coronary syndromes: a systematic review. Int J Cardiol 2013, 164:151-157.

54. Willems A, Van Lerberghe C, Gonsette K, De Villé A, Melot C, Hardy JF, Van der Linden P: The indication for perioperative red blood cell transfusions is a predictive risk factor for severe postoperative morbidity and mortality in children undergoing cardiac surgery. Eur J Cardiothorac Surg 2014. In press.

55. Middelburg RA, van de Watering LMG, van der Bom JG: Blood transfusions: good or bad? Confounding by indication, an underestimated problem in clinical transfusion research. Transfusion 2010, 50:1881-1883.

56. Lacroix J: Red cell transfusion: risk marker or risk factor in cardiac patients? Pediatr Crit Care Med 2013, 14:330-331.

57. Hendrickson JE, Hillyer CD: Noninfectious serious hazards of transfusion. Anesth Analg 2009, 108:759-769.

58. Taylor C, Cohen H, Mold D, Jones H, Davies T, Asher D, Cawley C, Chaffe B, Chapman C, Gray A, Knowles S, Milkins C, New H, Norfolk D, Still E, Tinegate $\mathrm{H}$, on behalf of the Serious Hazards of Transfusion (SHOT) Steering Group: The 2008 Annual SHOT Report. 2009, 153.

59. Tucci M, Lacroix J, Gauvin F, Toledano B, Robitaille N: Transfusion medicine. In Pediatric critical care medicine: Basic science and clinical evidence. 2nd edition. Edited by Wheeler DS, Wong HR, Shanley TP. London: Springer-Verlag; 2014. In press.

60. Barr PJ, Donnelly M, Cardwell CR, Parker M, Morris K, Bailie KE: The appropriateness of red blood cell use and the extent of overtransfusion: right decision? Right amount? Transfusion 2011, 51:1684-1694.

61. Sabatine MS, Morrow DA, Giugliano RP, Burton PB, Murphy SA, McCabe CH, Gibson CM, Braunwald E: Association of hemoglobin levels with clinical outcomes in acute coronary syndromes. Circulation 2005, 111:2042-2049.

62. Vamvakas EC, Blajchman MA: Transfusion-related immunomodulation (TRIM): an update. Blood Rev 2007, 21:327-348.

63. Gajic O, Gropper MA, Hubmayr RD: Pulmonary edema after transfusion: how to differentiate transfusion-associated circulatory overload from transfusion-related acute lung injury. Crit Care Med 2006, 34(5 Suppl):S109-S113

64. Vlaar AP, Cornet AD, Hofstra JJ, Porcelijn L, Beishuizen A, Kulik W, Vroom MB, Schultz MJ, Groeneveld AB, Juffermans NP: The effect of blood transfusion on pulmonary permeability in cardiac surgery patients: a prospective multicenter cohort study. Transfusion 2012, 52:82-90.

65. Tuinman PR, Vlaar AP, Cornet AD, Hofstra JJ, Levi M, Meijers JC, Beishuizen A, Schultz MJ, Groeneveld AJ, Juffermans NP: Blood transfusion during cardiac surgery is associated with inflammation and coagulation in the lung: a case control study. Crit Care 2011, 15:R59.

66. Vlaar AP, Binnekade JM, Prins D, van Stein D, Hofstra JJ, Schultz MJ, Juffermans N: Risk factors and outcome of transfusion-related acute lung injury in the critically ill: a nested case-control study. Crit Care Med 2010, 38:771-778.

67. Gajic O, Rana R, Winters $J$, Yilmaz M, Mendez $J$, Rickman OB, O'Byrne MM, Evenson LK, Malinchoc M, DeGoey SR, Afessa B, Hubmayr RD, Moore SB:
Transfusion-related acute lung injury in the critically ill: prospective nested case-control study. Am J Respir Crit Care Med 2007, 176:886-891.

68. Yalavatti GS, DeBacker D, Vincent JL: Assessment of cardiac index in anemic patients. Chest 2000, 118:782-787.

69. Weiskopf RB, Viele MK, Feiner J, Kelley S, Lieberman J, Noorani M, Leung JM, Fisher DM, Murray WR, Toy P, Moore MA: Human cardiovascular and metabolic response to acute, severe isovolemic anemia. JAMA 1998, 279:217-221.

70. Weiskopf RB, Feiner J, Hopf HW, Viele MK, Watson JJ, Kramer JH, Ho R, Toy $P$ : Oxygen reverses deficits of cognitive function and memory and increased heart rate induced by acute severe isovolemic anemia. Anesthesiology 2002, 96:871-877.

71. Frank SM, Abazya B, Ono M, Hogue CW, Cohen DB, Berkowitz DE, Ness PM, Barodka VM: Decreased erythrocyte deformability after transfusion and the effects of erythrocyte storage duration. Anesth Analg 2013, 116:975-981.

72. Rogers S, Doctor A: Vasoregulation by red blood cells. In Current Concepts in Pediatric Critical Care. Edited by Spinella PC, Nakagawa TA. Des Plaines: Society of Critical Care Medicine; 2011:21-39.

73. Bracey AW, Radovancevic R, Riggs SA, Houston S, Cozart H, Vaughn WK Radovancevic B, McAllister HA, Cooley DA: Lowering the hemoglobin threshold for transfusion in coronary artery bypass procedures: effect on patient outcome. Transfusion 1999, 39:1070-1077.

74. Carson JL, Terrin ML, Noveck H, Sanders DW, Chaitman BR, Rhoads GG, Nemo G, Dragert K, Beaupre L, Hildebrand K, Macaulay W, Lewis C, Cook DR, Dobbin G, Zakriya KJ, Apple FS, Horney RA, Magaziner J, for the FOCUS Investigators: Liberal or restrictive transfusion in high-risk patients after hip surgery. N Engl J Med 2011, 365:2453-2462.

75. Transfusion Requirements in Critical Care Investigators for the Canadian Critical Care Trials Group, Hébert PC, Yetisir E, Martin C, Blajchman MA, Wells G, Marshall J, Tweeddale M, Pagliarello G, Schweitzer I: Is a low transfusion threshold safe in critically ill patients with cardiovascular diseases? Crit Care Med 2001, 29:227-234

76. Johnson RG, Thurer RL, Kruskall MS, Sirois C, Gervino EV, Critchlow J, Weintraub RM: Comparison of two transfusion strategies after elective operations for myocardial revascularization. J Thorac Cardiovasc Surg 1992, 104:307-314.

77. Cholette JM, Rubenstein JS, Alfieris GM, Powers KS, Eaton M, Lerner NB: Children with single ventricle physiology do not benefit from higher hemoglobin levels following cavopulmonary connection: Results of a prospective, randomized controlled trial of a restrictive v. liberal red cell transfusion strategy. Pediatr Crit Care Med 2011, 12:39-45.

78. de Gast-Bakker DH, de Wilde RBP, Hazekamp MG, Sojak V, Zwaginga JJ, Wolterbeek R, de Jonge E, der Veer BJG-V: Safety and effects of two red blood cell transfusion strategies in pediatric cardiac surgery patients; a randomized controlled trial. Intensive Care Med 2013, 39:2011-2019.

79. For the Canadian Critical Care Trials Group and the Pediatric Acute Lung Injury and Sepsis Investigators (PALISI) Network, Willems A, Harrington K, Lacroix J, Biarent D, Joffe A, Wensley D, Hébert P, Tucci M: Comparison of two red-cell transfusion strategies after pediatric cardiac surgery. Crit Care Med 2010, 38:649-656.

80. The Transfusion Requirements in Critical Care Investigators, Hébert PC, Wells G, Blajchman MA, Marshall J, Martin C, Pagliarello G, Tweeddale M, Schweitzer I, Yertsir E: A multicenter, randomized, controlled clinical trial of transfusion requirements in critical care. N Engl J Med 1999, 340:409-417.

81. Lacroix J, Hébert PC, Hutchison JH, Hume H, Tucci M, Ducruet T, Gauvin F, Collet JP, Toledano BJ, Robillard P, Joffe A, Biarent D, Meert K, Peters MJ, on behalf of the TRIPICU investigators, for the Canadian Critical Care Trials Group and the Pediatric Acute Lung Injury and Sepsis Investigators (PALISI) Network: Transfusion strategies for patients in pediatric intensive care units. N Engl J Med 2007, 356:1609-1619.

82. Rivers E, Nguyen B, Havstad S, Ressler J, Muzzin A, Knoblich B, Peterson E, Tomlanovich M: Early goal-directed therapy in the treatment of severe sepsis and septic shock. N Engl J Med 2001, 345:1368-1377.

83. Bhalala US, Nishisaki A, McQueen D, Bird GL, Morrison WE, Nadkarni VM, Nathan M, Starr JP: Change in regional (somatic) near-infrared spectroscopy is not a useful indicator of clinically detectable low cardiac output in children after surgery for congenital heart defects. Pediatr Crit Care Med 2012, 13:529-534.

84. Creteur J, Neves AP, Vincent JL: Near-infrared spectroscopy technique to evaluate the effects of red blood cell transfusion on tissue oxygenation. Crit Care 2009, 13(Suppl 5):S11. 
85. de Oliveira CF, de Oliveira DS, Gottschald AF, Moura JD, Costa GA, Ventura AC, Fernandes JC, Vaz FA, Carcillo JA, Rivers EP, Troster EJ: ACCM/ PALS haemodynamic support guidelines for paediatric septic shock: an outcomes comparison with and without monitoring central venous oxygen saturation. Intensive Care Med 2008, 34:1065-1075.

86. The ProCESS Investigators: A randomized trial of protocol-based care for early septic shock. N Engl J Med 2014, 370:1683-1693.

87. Antman EM, Anbe DT, Armstrong PW, Bates ER, Green LA, Hand M,

Hochman JS, Krumholz HM, Kushner FG, Lamas GA, Mullany CJ, Ornato JP, Pearle DL, Sloan MA, Jr Smith SC, American College of Cardiology; American

Heart Association; Canadian Cardiovascular Society: ACC/AHA guidelines for the management of patients with ST-elevation myocardial infarction - executive summary. A report of the American College of Cardiology/American Heart Association Task Force on Practice Guidelines (Writing Committee to revise the 1999 guidelines for the management of patients with acute myocardial infarction). J Am Coll Cardiol 2004, 44:671-719.

doi:10.1186/2110-5820-4-16

Cite this article as: Du Pont-Thibodeau et al: Anemia and red blood cell transfusion in critically ill cardiac patients. Annals of Intensive Care 2014 4:16.

\section{Submit your manuscript to a SpringerOpen ${ }^{\circ}$ journal and benefit from:}

- Convenient online submission

- Rigorous peer review

- Immediate publication on acceptance

- Open access: articles freely available online

- High visibility within the field

- Retaining the copyright to your article 